\title{
Metamorphic Temperature Investigation of Coexisting Calcite and Dolomite Marble_Examples from Nikani Ghar Marble and Nowshera Formation, Peshawar Basin, Pakistan
}

\author{
Muhammad Fahad ${ }^{1,2}$, Yaseen Iqbal*2, Mohammad Riaz ${ }^{3}$, Rick Ubic ${ }^{4}$, Simon A. T. Redfern $^{5}$ \\ 1. Department of Electrical Engineering, COMSATS Institute of Information Technology, Abbottabad 22010, Pakistan \\ 2. Materials Research Laboratory, Department of Physics, University of Peshawar, Peshawar 25120, Pakistan \\ 3. National Centre of Excellence in Geology, University of Peshawar, Peshawar 25120, Pakistan \\ 4. College of Engineering Boise State University, Boise 83401, USA \\ 5. Department of Earth Sciences, University of Cambridge, Cambridge 999020, United Kingdom
}

\begin{abstract}
Using marble samples from the Nikani Ghar marble and Nowshera Formation from Northern Pakistan the determination of the temperature of metamorphism was undertaken with the help of calcite-dolomite solvus geothermometer. Two types of marbles, that is, calcite-dolomite marble and quartz-bearing calcite-dolomite marble were selected. Petrographic and scanning electron microscope analysis of dolomite samples indicated different grain sizes. $X$-ray diffraction technique indicated the calcites $\mathrm{MgCO}_{3}$ content up to 7.93 mol.\%. Nikani Ghar marble samples have shown lower contents of $\mathrm{MgCO}_{3}$ as compared to samples from Nowshera Formation. The calcite-dolomite-quartz marble has also showed relatively lower $\mathrm{MgCO}_{3}$ content and hence rather low temperature $\left(\sim 500{ }^{\circ} \mathrm{C}\right)$. The temperature reached during peak metamorphism of the investigated marble occurrence, based on calcitedolomite solvus was $628^{\circ} \mathrm{C}$. Metamorphic temperatures derived from the present study were shown as a linear graph and values were in good agreement with the published literature.

KEY WORDS: calcite, dolomite, metamorphic temperature, geothermometer, X-ray diffraction.
\end{abstract}

\section{INTRODUCTION}

Determining peak metamorphic temperature of low grade rocks has always been a challenge. X-ray diffraction (XRD) is an established technique for the determination of constituent phases in solid-solution series. Differences in ionic sizes between substitute and host cations lead to systematic variations in unit-cell parameters and inter-planar spacings that can be measured using XRD. This approach has been widely used in analyzing rhombohedral Ca-Mg carbonates, for example, the composition of biogenic and inorganic $(\mathrm{Ca}, \mathrm{Mg}) \mathrm{CO}_{3}$ crystals are often calculated by comparing the difference in $d_{104}$ value with the published determinative curves (Zhang et al., 2010; Raz et al., 2000; Falini et al., 1996; Bischoff et al., 1983; Milliman et al., 1971). At least five empirical curves are currently known in the literature (Bischoff et al., 1983; Milliman et al., 1971; Goldsmith et al., 1961, 1955; Goldsmith and Graf, 1958; Chave, 1952). Determinative curves based on synthetic magnesian calcite crystals are probably the most widely used (Milliman et al., 1971; Goldsmith et al., 1961; Goldsmith and Graf, 1958).

Owing to the abundance of calcite and dolomite in the

*Corresponding author: dryaseeniqbal@yahoo.co.uk

(C) The Authors 2016. This article is published with open access at Springerlink.com

Manuscript received July 24, 2014.

Manuscript accepted November 7, 2014.
Earth's crust, knowledge of their limits of stability can be used to assess the conditions of temperature prevailing during their formation and subsequent metamorphism. The calcite-dolomite solvus in the system $\mathrm{CaCO}_{3}-\mathrm{MgCO}_{3}$ was first investigated by Graf and Goldsmith (1955) and Harker and Tuttle (1955). They recognized that the temperature dependence of the amount of $\mathrm{MgCO}_{3}$ in calcite in equilibrium with dolomite is potentially a precise method of estimating metamorphic temperatures. Graf and Goldsmith $(1958,1955)$ and Goldsmith et al., (1955) used XRD to determine the $\mathrm{MgCO}_{3}$ content in natural and synthetic samples to establish phase relationships in the $\mathrm{CaO}-\mathrm{MgO}-\mathrm{CO}_{2}$ system from the concentration of 0 to $15 \mathrm{~mol} . \%$ of $\mathrm{MgCO}_{3}$. Later on, calcite-dolomite thermometry has been widely used (e.g., Wada and Suzuki, 1983; Bowman and Essene, 1982; Iii et al., 1982; Nesbitt and Essene, 1982; Ralph and Diane, 1980; Rice, 1977; Suzuki, 1977; Puhan, 1976; Hatcher et al., 1973; Hutcheon and Moore, 1973; Sobol, 1973).

Talantsev (1978, 1976), Bickle and Powell (1977), and Barron (1974) evaluated the effect of $\mathrm{FeCO}_{3}$ on calcitedolomite thermometry and reported that its effect is negligible at concentrations $<1$ mol.\%. Bickle and Powell (1977) reported that the metamorphic temperature of coexisting calcitedolomite samples from the Glockner area of the Tauern Window, Austria ranged from 410 to $490{ }^{\circ} \mathrm{C}$. The solvus temperature determined from XRD data for Grenville calcite ranged from 415 to $485{ }^{\circ} \mathrm{C}$ (Sheppard, 1966). Höy (1970) estimated a temperature of $600{ }^{\circ} \mathrm{C}$ by using the calcite from brucite marble.

Fahad, M., Iqbal, Y., Riaz, M., et al., 2016. Metamorphic Temperature Investigation of Coexisting Calcite and Dolomite MarbleExamples from Nikani Ghar Marble and Nowshera Formation, Peshawar Basin, Pakistan. Journal of Earth Science, 27(6): $989-997$. doi:10.1007/s12583-015-0643-7. http://en.earth-science.net 
Puhan (1976) determined the metamorphic temperature of marble samples from the Damara Orogen, Southwest Africa and reported $620{ }^{\circ} \mathrm{C}$ temperature based on dolomite-calcite geothermometer.

Goldsmith and Newton (1969) calculated the pressure effect on the solubility of $\mathrm{MgCO}_{3}$ in calcite by a regular solution theory. They reported that the effect of total pressure on the solubility of $\mathrm{MgCO}_{3}$ in the calcite structure was about 0.12 mol.\% per $\mathrm{kb}$ at temperatures ranging from 500 to $800{ }^{\circ} \mathrm{C}$. They applied calcite-dolomite geothermometer for metamorphic temperature evaluation, based on the solubility of magnesium in calcite in the calcite+dolomite assemblage, which has been shown to be more sensitive to temperature than pressure.

In this work the coexisting calcite-dolomite marbles from Nikani Ghar marble and Nowshera Formation (northern Pakis$\tan$ ) were thoroughly investigated for the first time for determination of temperature of metamorphism using the magnesian calcite geothermometer. Temperatures were evaluated by applying the calcite-dolomite geothermometer (Goldsmith and Newton, 1969), based on the solubility of magnesium in calcite in the calcite+dolomite assemblage. The magnesium content of calcite coexisting with dolomite (expressed as mol.\% $\mathrm{MgCO}_{3}$ ) was estimated by both XRD and electron microprobe (EMPA) operating in the energy dispersive (EDS) mode and the stoichiometric composition of $\mathrm{CaCO}_{3}$ was determined.

\section{MATERIALS AND METHODS}

\subsection{Study Region}

The variety of metamorphic rocks in Himalayas is astounding. Accordingly, there is no dearth of scientific literature on deciphering the metamorphic history of these rocks. In general, the northern Pakistan is home to medium and high-grade metamorphic rocks; however, the Sub-Lesser Himalayas (i.e., Himalayan hinterland) exhibit a huge swath of low grade metamorphic rocks. The Peshawar Basin is part of the Lesser Himalayas. The study area lies between the foreland of the main mantle thrust (MMT) and hinterland of the main boundary thrust (MBT) and hence defining the Peshawar Basin. The MMT, in general, defines the northern margin of the Indian plate in Pakistan (DiPietro et al., 2000) and is consequently deformed extensively (Fig. 1). The deformation style is a combination of folding, foreland-directed thrusting and regional metamorphism (Pogue et al., 1992; DiPietro and Lawrence, 1991; Lawrence et al., 1985; Rosenberg, 1985). The MBT is a regional thrust that separates pre- and post-Himalayan rocks. The rocks of Jurassic Nikani Ghar marble have been found to

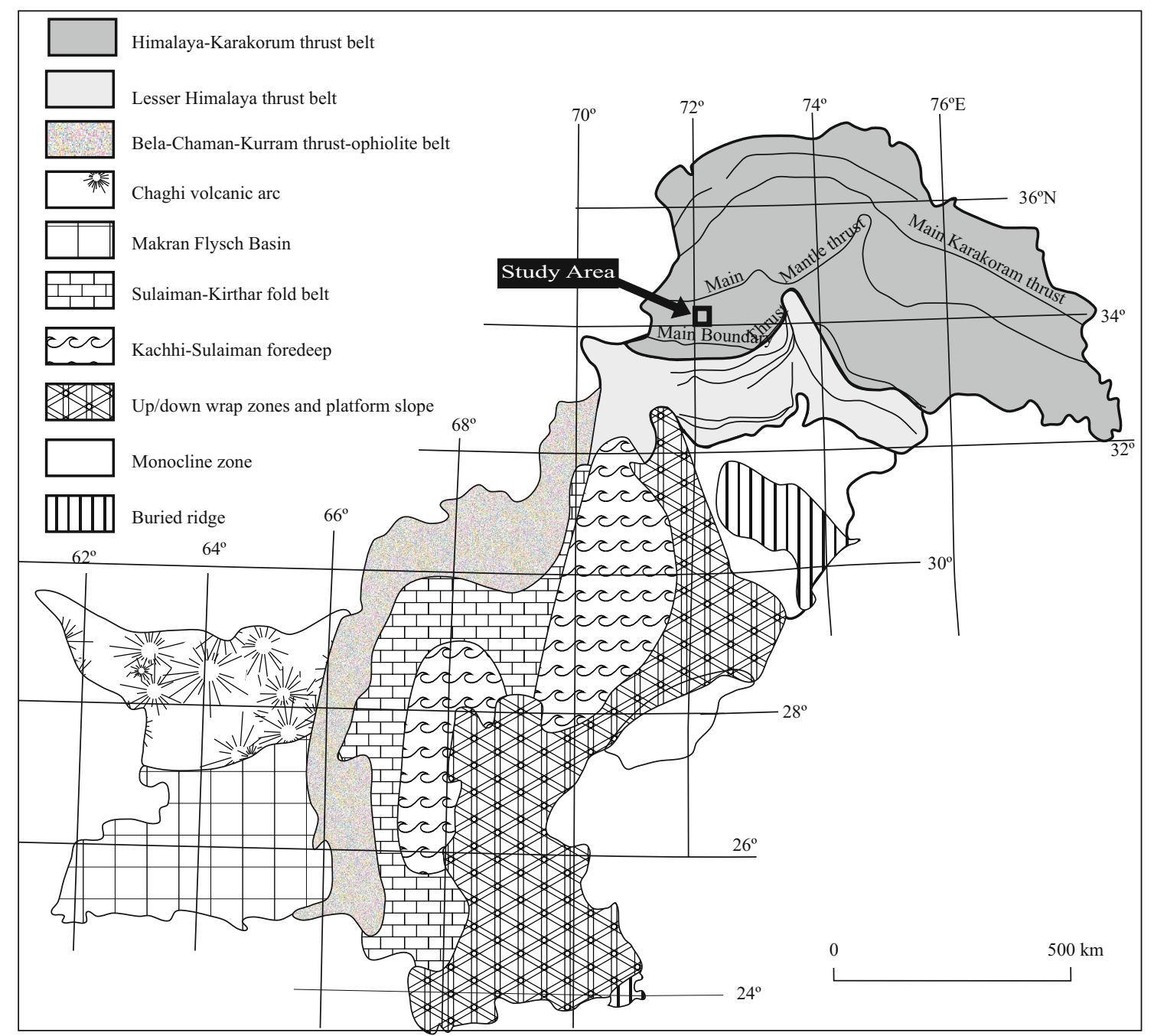

Figure 1. Tectonic map of Pakistan (modified from Kazmi and Rana, 1982), showing location of the study area within the tectonic domain of Pakistan. 
undergo multiple deformations with at least four periods of folding during a single Paleogene metamorphism (DiPietro and Lawrence, 1991). These rocks are generally fine to mediumgrained with occasional coarse-grain varieties at places, dominantly composed of calcite with minor ore, quartz and traces of dolomitized grains.

The grains are subhedral to anhedral. Ahmed (1986) reported that the amphibolites exposed in the area were igneousin nature indicating that the area was 'thermally' disturbed during and after regional metamorphism. An igneous injection tends to follow a path of mechanically weak zone, e.g., fractures and bedding planes. The process of injection in itself creates further mechanical instabilities like fractures, cracks and localized 'baking' effects. In this area granite magmatism is common. The MBT was mainly responsible for exposing the oldest Paleozoic rocks (e.g., Nowshera Formation) on the southern margin of the Peshawar Basin. The Nowshera Formation is mainly composed of recrystallized impure limestone and dolomite with subordinate phyllite, crinoidal limestone and quartzite in the southern part (Nowshera) of Peshawar Basin and has calcite and dolomitic marble in its northern exposures (i.e., near Swabi). It is equigranular, compact and hard. The bedding is medium to thick and massive. The deposits are not extensive and appear in isolated small outcrops. The marble contains various calcite filled veins, veinlet's and cavities. Yellowish to dark brown coatings and patches of ferruginous

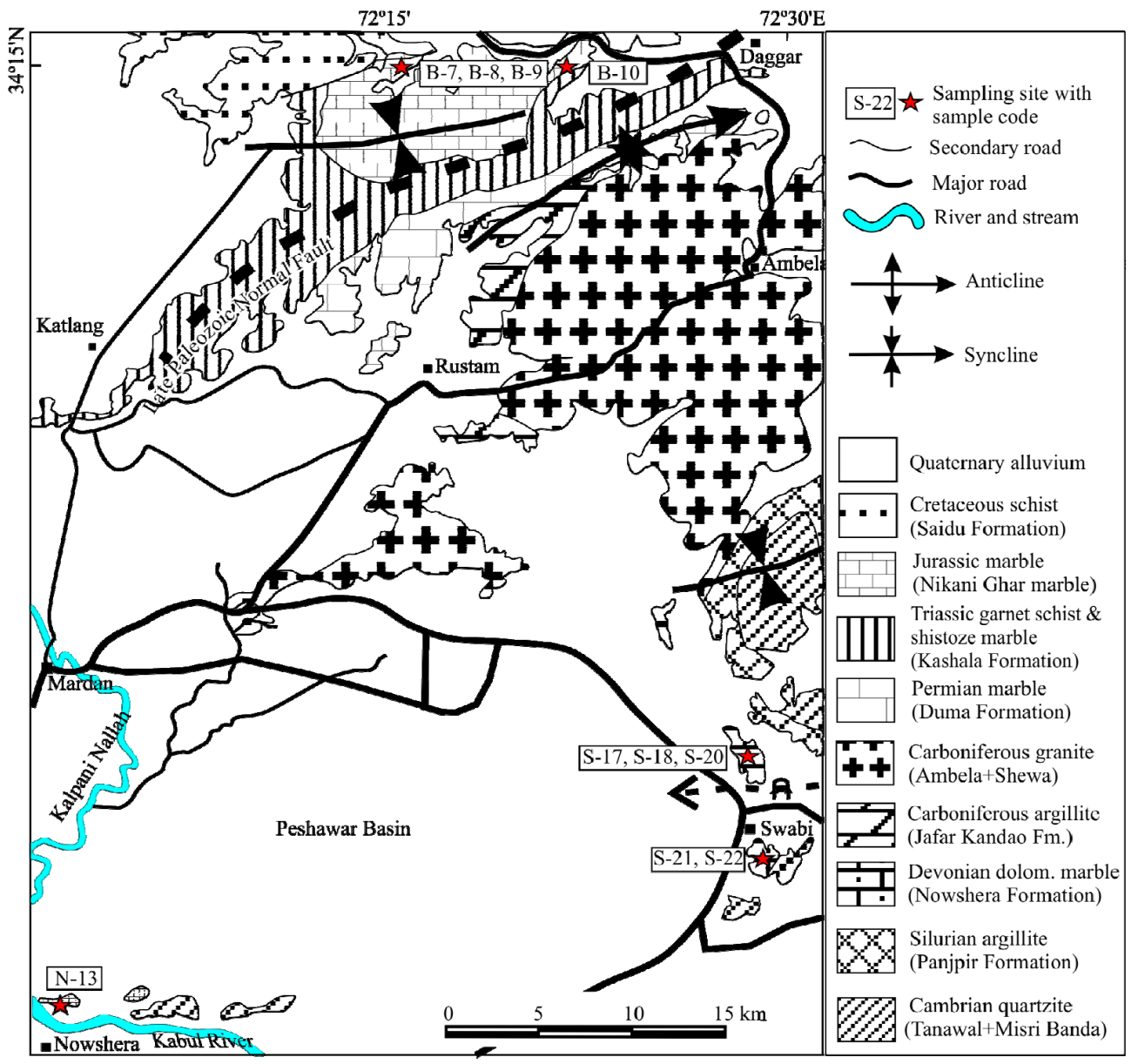

Figure 2. Geological map of the study area extracted (modified and redrawn from Hussain et al., 2004).

Table 1 Location and description of specimens

\begin{tabular}{|c|c|c|c|c|c|}
\hline Sample & Description & Collection location & \multicolumn{3}{|c|}{ GPS data } \\
\hline $\mathrm{BN}-13$ & Calcite-dolomite marble & Nikani Ghar marble (Buner District) & 34.5017 & 72.2879 & $790 \pm 26$ \\
\hline $\mathrm{BN}-35$ & Calcite-dolomite marble & & 34.4946 & 72.2622 & $813 \pm 37$ \\
\hline $\mathrm{BN}-46$ & Calcite-dolomite marble & & 34.4946 & 72.2622 & $813 \pm 37$ \\
\hline NW-612 & Calcite-dolomite marble & & 34.0294 & 71.9981 & $262 \pm 22$ \\
\hline NW-714 & Calcite-dolomite-quartz marble & & 34.0149 & 72.0308 & $282 \pm 20$ \\
\hline NW-815 & Calcite-dolomite-quartz marble & & 34.0151 & 72.0285 & $307 \pm 15$ \\
\hline SW-919 & Calcite-dolomite marble & Nowshera Formation (Swabi District) & 34.2139 & 72.4181 & $345 \pm 45$ \\
\hline
\end{tabular}


material are also found along these fillings. The marble also contains fossil remains, which gives the polished surface a very attractive appearance.

The present study targets three major areas (i.e., Nowshera, Swabi and Buner districts, Pakistan) for Nikani Ghar marble and Nowshera Formation that rim the Peshawar Basin (Fig. 2). A total of 9 samples were collected from these formations (marked with sample numbers in Fig. 2) and location of the investigated specimens are given in Table 1. The samples are classified on the basis of collection area and their mineralogicalcomposition. In this study two types of marbles were selected: calcite-dolomite marble and quartz-bearing calcitedolomite marble. Calcite-dolomite marble is classified as a distinct unit because of the predominant calcite and dolomite phases. The dolomite grain size varies from sample to sample. Quartz-bearing calcite-dolomite marble is named because of the presence of quartz in substantial amount. Calcite is the major mineral and is generally medium to coarse grained $(\geq 400 \mu \mathrm{m})$. Dolomite occurs in minor amounts.

\subsection{Characterization Methods}

A Zeiss-Axioplan-1 polarizing photomicroscope with a Canon A630 digital camera was used for petrographic analysis. $\mathrm{XRD}$ was used to determine the $\mathrm{MgCO}_{3}$ content in calcite as it has been reported as the most accurate method for the determination of $\mathrm{MgCO}_{3}$ content in magnesian calcite (Goldsmith and Newton 1969). It is often difficult to determine the composition of many run-products using electron microprobe (EMPA) because of their fine-grained nature (Powell et al., 1984) while inter-planar spacings ( $d$-values) are sensitive to compositional variations; therefore, to avoid erroneous results e.g., in the case of coherent submicroscopic intergrowths, XRD was used. For XRD, marble samples were powdered using a mortar and pestle system and back-filled into glass sample-holders or evenly spread over the surface of a glass slide using a small amount of acetone. After drying, the samples were inserted into the X-ray diffractometer.

A Bruker AXS advanced D8 discover XRD, operating at $40 \mathrm{kV}$ power and $40 \mathrm{~mA}$ current, with $\mathrm{Cu} \mathrm{k} \alpha$ radiations $(\lambda \sim 1.54$ $\AA$ ) was used at the Department of Earth Sciences, University of Cambridge (UK). The samples were scanned from $2 \theta=5^{\circ}$ to $90^{\circ}$, at $0.3^{\circ} / \mathrm{min}$ with a step size of $0.02^{\circ}$. A Cameca SX-100 electron microprobe operated at $15 \mathrm{kV}$ and $10 \mathrm{nA}$ with a time constant of $5 \mathrm{~s}$ (University of Cambridge, UK) was used for the determination of core composition of the rock. The Rietveld refinement method was used for the determination of unit cell parameters of coexisting calcite-dolomite crystals.

The magnesium-content embedded within calcite was used in the determination of its metamorphic temperature and as mentioned earlier, XRD is the most accurate method for the determination of $\mathrm{MgCO}_{3}$ content in magnesian calcite (Goldsmith and Newton, 1969). The relationship between the $\mathrm{MgCO}_{3}$ content of calcite and its $d$-spacings has been reported by Goldsmith et al., (1955). The $d_{104}$ values determined by XRD for calcite were converted into $\mathrm{MgCO}_{3}$ mol.\%. The Rietveld method employs the entire powder diffraction pattern, thereby overcoming the problem of peak overlap. In this method, each data point ( $2 \theta$-step) is considered as an observation, which thus allows the maximum amount of information to be extracted from the pattern. During the refinement procedure, structural parameters, background coefficients, and profile parameters are varied in a least-squares procedure until the calculated powder profile, based on the structure model, best matches the observed pattern (Rietveld, 1969, 1967). The General Structure Analysis System (GSAS) program with EXPGUI, a graphical user interface for GSAS was used for the Rietveld refinement analyses (Toby, 2001; Larson and Dreele, 1994). Chemical analysis was performed by X-ray fluorescence spectroscopy (XRF). Scanning electron microscopy (SEM) observation was performed on $4 \times 4 \times 4 \mathrm{~mm}^{3}$ samples which were polished and gold coated before using in a JEOL JSM 5910 SEM at the Centralized Resource Laboratory, University of Peshawar (Pakistan).

\section{RESULTS AND DISCUSSIONS}

The dolomite marble specimens contained $2.5 \mathrm{~mol} \%$ to 7.93 mol.\% $\mathrm{MgCO}_{3}$ (Table 2). From the composition point of view, Nikani Ghar marble samples (except sample BN-35, Table 2) contained lower amounts of $\mathrm{MgCO}_{3}$ than the samples from Nowshera Formation (except samples NW-714 and NW815). The observed variation in $\mathrm{MgCO}_{3}$ content may be due to the variation in the mineralogy of the samples because the mineral assemblages were different at different locations. Samples from Nikani Ghar marble were composed mainly of calcite, dolomite (XRD) and apatite, quartz or pyrite in some specimens while samples from Nowshera Formation were composed of iron-oxide, quartz, muscovite and pyrite in addition to carbonates. The samples NW-511 and NW-612 from Nowshera Formation were mainly composed of calcite and dolomite but contained the highest $\mathrm{MgCO}_{3}$ content among the tested calcites (Table 2). The calcite of quartz-bearing calcitedolomite marble (samples NW-714, NW-815) showed relatively lower $\mathrm{MgCO}_{3}$ content (Table 2).

Thin-section optical microscopy (Figs. 3a, 4b) and SEM (Figs. $4 a, 4 b$ ) revealed the presence of two generations of dolomite.

(a) The generation corresponding to large dolomite crystals $(>140 \mu \mathrm{m})$ with rhombohedral form, may be the primary mineral.

(b) The second generation corresponding to calcite which

Table 2 The molar persetage $\left[\Delta d_{104}\right.$, X-ray diffractometer] of $\mathrm{MgCO}_{3}$, and metamorphic temperature of investigated marble samples from Nowshera Formation and Nikani Ghar marble calculated using calibrations from Goldsmith and Newton (1969)

\begin{tabular}{lccc}
\hline Sample & $\Delta d_{104}(\AA)$ & $\mathrm{MgCO}_{3}(\mathrm{~mol} . \%)$ & $T\left({ }^{\circ} \mathrm{C}\right)$ \\
\hline BN-13 & 0.006 & 2.50 & 414 \\
BN-24 & 0.015 & 5.20 & 546 \\
BN-35 & 0.018 & 6.87 & 592 \\
BN-46 & 0.009 & 3.50 & 460 \\
NW-511 & 0.020 & 7.10 & 603 \\
NW-612 & 0.022 & 7.93 & 628 \\
NW-714 & 0.012 & 4.50 & 504 \\
NW-815 & 0.012 & 4.50 & 504 \\
SW-919 & 0.016 & 5.82 & 558 \\
\hline
\end{tabular}



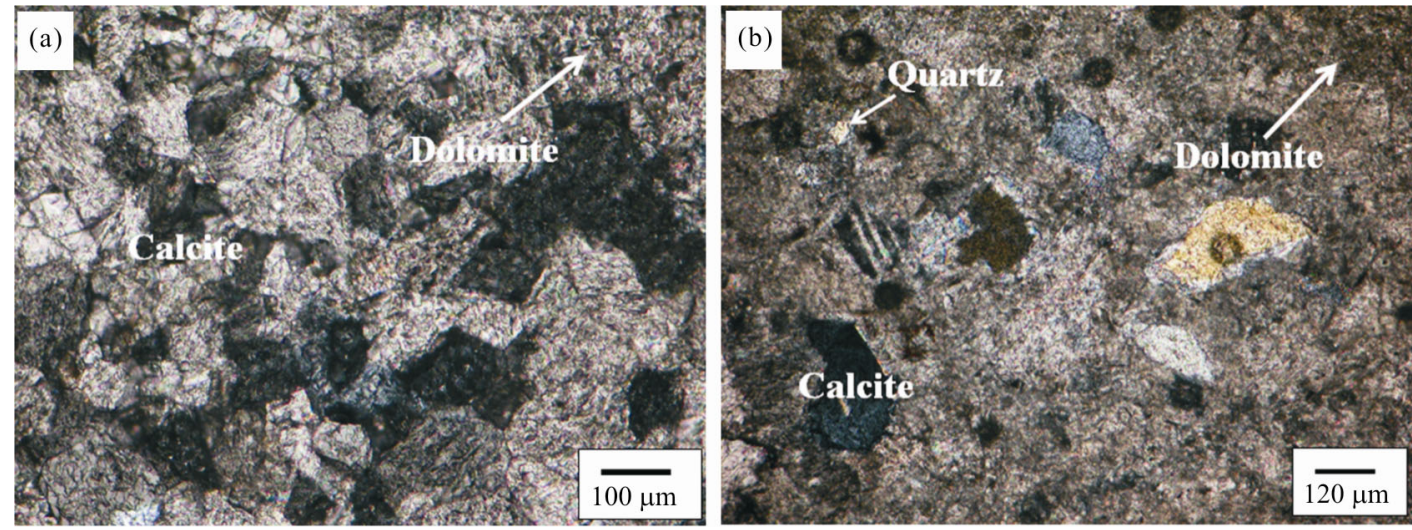

Figure 3. Polarized light micrographs of thin-sections showing "bleb-like" textural features of (a) BN-46 and (b) NW-815 samples.
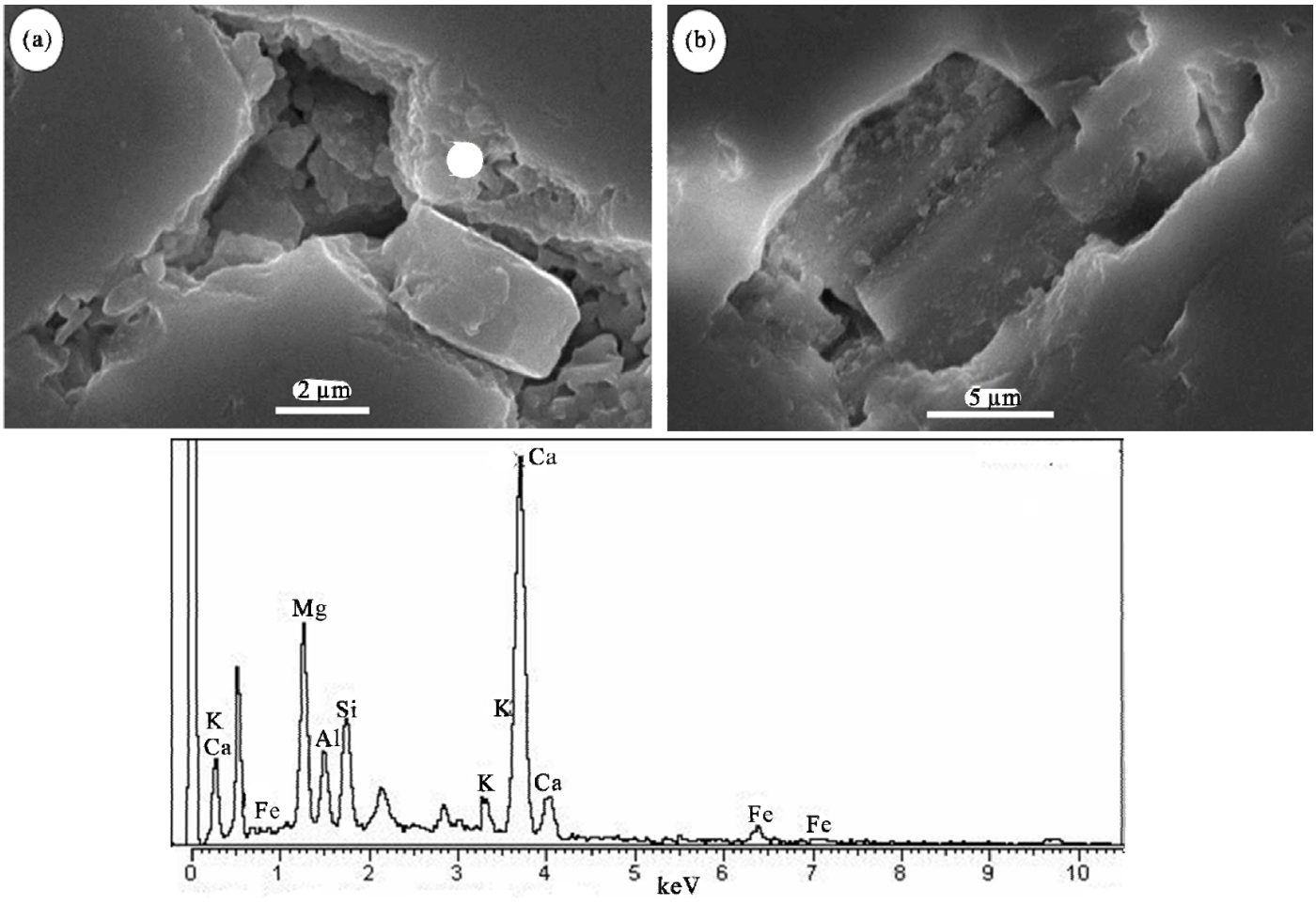

Figure 4. SEIs of (a) NW-511 and (b) NW-612 samples showing presence of fine grained dolomite.

Table 3 XRF analysis of the investigated samples (wt.\%)

\begin{tabular}{lccccccccccccc}
\hline Sample ID & $\mathrm{SiO}_{2}$ & $\mathrm{TiO}_{2}$ & $\mathrm{Al}_{2} \mathrm{O}_{3}$ & $\mathrm{Fe}_{2} \mathrm{O}_{3}$ & $\mathrm{MnO}$ & $\mathrm{MgO}$ & $\mathrm{CaO}$ & $\mathrm{Na}_{2} \mathrm{O}$ & $\mathrm{K}_{2} \mathrm{O}$ & $\mathrm{P}_{2} \mathrm{O}_{5}$ & $\mathrm{SO}_{3}$ & $\mathrm{SrO}$ & $\mathrm{LOI}$ \\
\hline $\mathrm{BN}-13$ & 0.189 & 0.000 & 0.463 & 0.041 & 0.000 & 2.340 & 51.183 & 3.395 & 0.000 & 0.000 & 0.000 & 0.000 & 42.39 \\
$\mathrm{BN}-24$ & 0.902 & 0.000 & 0.706 & 0.085 & 0.000 & 2.789 & 48.479 & 4.466 & 0.049 & 0.001 & 0.023 & 0.000 & 42.50 \\
$\mathrm{BN}-35$ & 1.059 & 0.000 & 0.820 & 0.152 & 0.017 & 2.706 & 49.944 & 3.333 & 0.070 & 0.000 & 0.000 & 0.000 & 41.90 \\
$\mathrm{BN}-46$ & 0.068 & 0.000 & 0.252 & 0.050 & 0.000 & 17.685 & 35.934 & 0.312 & 0.000 & 0.000 & 0.000 & 0.000 & 45.70 \\
$\mathrm{NW}-11$ & 0.904 & 0.020 & 0.943 & 0.091 & 0.059 & 9.688 & 41.515 & 2.619 & 0.064 & 0.003 & 0.000 & 0.017 & 44.92 \\
$\mathrm{NW}-612$ & 0.685 & 0.021 & 0.688 & 0.181 & 0.044 & 9.846 & 44.220 & 1.684 & 0.063 & 0.003 & 0.000 & 0.017 & 44.92 \\
$\mathrm{NW}-714$ & 18.11 & 0.098 & 1.289 & 0.197 & 0.000 & 1.040 & 45.722 & 3.058 & 0.276 & 0.000 & 0.000 & 0.000 & 30.21 \\
$\mathrm{NW}-815$ & 3.119 & 0.093 & 1.580 & 0.283 & 0.033 & 1.989 & 50.680 & 1.474 & 0.409 & 0.001 & 0.000 & 0.000 & 40.34 \\
$\mathrm{SW}-919$ & 2.524 & 0.057 & 1.171 & 0.156 & 0.039 & 17.08 & 34.599 & 0.026 & 0.167 & 0.000 & 0.000 & 0.000 & 43.88 \\
\hline
\end{tabular}

dissolved magnesium during metamorphism with the maximum at the highest temperature (Table 2). Upon cooling, magnesium exsolved from the calcite solid solution, thus "bleblike" dolomite is formed. These textures are noticed in samples
BN-46 and NW-815 (Figs. 3a, 3b). The calcite in such samples contained low amounts of magnesium in its structure; therefore, the temperature determination could give a low value. The small Fe peak in the EDS spectrum (Fig. 4) may be because of 
the sub-microscopic exclusion of iron bearing lamellae. Consistent with this result up to a maximum of up to $0.283 \mathrm{wt} . \%$ iron oxide was observed in XRF analysis of the investigated rocks (Table 3). Optical microscopy revealed less dolomite in few samples (e.g., in BN-13, BN-24 and BN-35), insufficient to be detected by XRD; however, the other magnesium-rich calcite samples demonstrated a strong dolomite reflection.

Curves of mol.\% $\mathrm{MgCO}_{3}$ vs. temperature were established by Goldsmith and Newton (1969), Graf and Goldsmith (1958, 1955), and Harker and Tuttle (1955). Figure 5 shows the temperatures derived from the present study and a comparison with the results reported by Goldsmith and Newton (1969). The values were found to be in good agreement. The $\mathrm{MgCO}_{3}$ content calculated from XRD data was found to be ranging from $2.50 \mathrm{~mol} . \%$ to $7.93 \mathrm{~mol} \%$. Consequently, the investigated calcite-dolomite marbles indicated a metamorphic temperature of formation ranging from 414 to $628^{\circ} \mathrm{C}$.

The observed variation in the metamorphic temperature for $\mathrm{BN}-13,-24,-35,-46$ may be due to the proximity to the fault (Fig. 1). It was noticeable that phyllite was present in the Nowshera Formation whereas the analyzed samples were from the northern part of the Peshawar Basin whereas the Nowshera Formation does not have any pelitic rocks. There are some localities near the sampling sites where garnet has been reported but it seems that this high temperature $\left(500-628^{\circ} \mathrm{C}\right)$ is because of the large scale faulting and not burial effect.

The quartz-bearing calcite-dolomite marble generally gave rather low temperature $\sim 500{ }^{\circ} \mathrm{C}$ (Table 2). This is in close range to the independently established peak metamorphism temperature of $400{ }^{\circ} \mathrm{C}$ by conodonts colour index (Pogue et al., 1992). These results are also presented in histogram form in Fig. 6. With regard to the EMPA with EDS of the whole rock sample, the resulting values of $\mathrm{MgCO}_{3}$ content were found to be ranging from $0.10 \mathrm{~mol} \%$ to $2.23 \mathrm{~mol} \%$, indicating the metamorphism temperature to be lower than $400{ }^{\circ} \mathrm{C}$. The chemical analysis with the XRF and EPMA-EDS for $\mathrm{MgCO}_{3}$ $(<2.23 \mathrm{~mol} . \%)$ for the investigated samples (Table 4) were consistently lower as compared to the present XRD findings

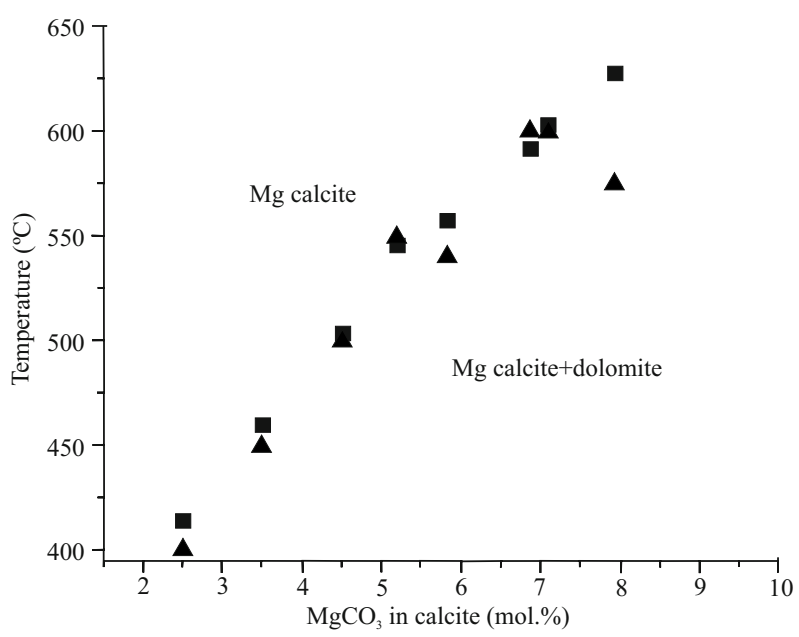

Figure 5. Calcite-dolomite solvus. Black colour square boxes (๘) denote runs made in this study and numbers are from Table 2 . Triangles $(\boldsymbol{\Delta})$ are data of Goldsmith and Newton (1969).

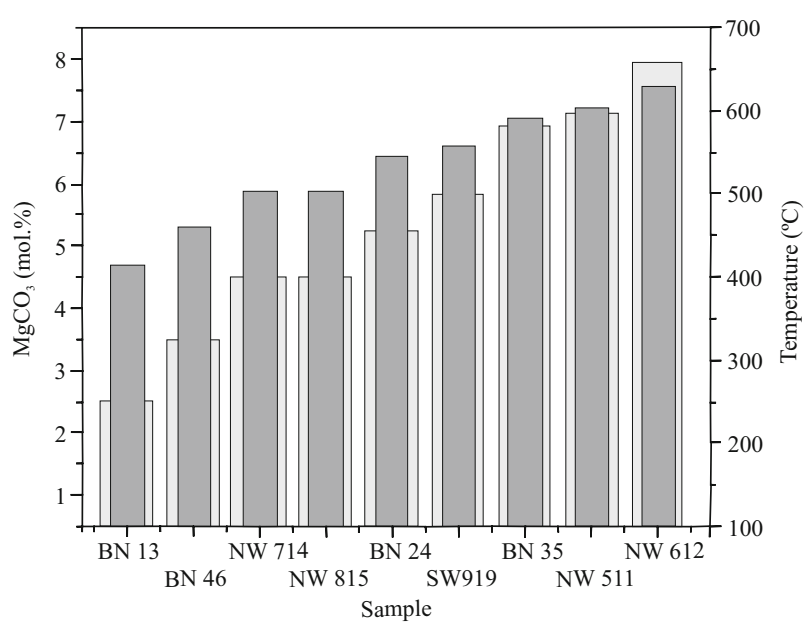

Figure 6. $\mathrm{MgCO}_{3}$ content in the whole rock (light grey) and metamorphic temperatures (dark grey) of investigated calcite-dolomite marble samples measured by XRD analysis (see data in Table 2) from Nowshera Formation and Nikani Ghar marble.

Table 4 Core composition of the calcite grains characterized by maximum Mg-content in investigated marble samples by EPMA-EDS from Nowshera Formation and Nikani Ghar marble

\begin{tabular}{|c|c|c|c|c|c|c|c|c|c|}
\hline Sample & $\mathrm{BN}-13$ & $\mathrm{BN}-24$ & $\mathrm{BN}-35$ & BN-46 & NW-511 & NW-612 & NW-714 & NW-815 & SW-919 \\
\hline \multicolumn{10}{|c|}{ wt.\% oxide } \\
\hline $\mathrm{CaO}$ & 55.47 & 59.21 & 55.50 & 60.48 & 58.88 & 60.08 & 58.69 & 58.92 & 58.36 \\
\hline $\mathrm{MgO}$ & 1.038 & 0.533 & 1.010 & 0.049 & 0.204 & 0.255 & 0.650 & 0.411 & 0.520 \\
\hline Sum & 56.51 & 59.74 & 56.51 & 60.53 & 59.08 & 60.33 & 59.34 & 59.33 & 58.88 \\
\hline $\mathrm{CO}_{2}$ & 43.49 & 40.26 & 43.49 & 39.47 & 40.92 & 39.67 & 40.66 & 40.67 & 41.12 \\
\hline Total & 100 & 100 & 100 & 100 & 100 & 100 & 100 & 100 & 100 \\
\hline \multicolumn{10}{|c|}{ No. of ions } \\
\hline $\mathrm{Ca}$ & 1.867 & 1.976 & 1.888 & 1.996 & 1.989 & 1.987 & 1.967 & 1.980 & 1.974 \\
\hline $\mathrm{Mg}$ & 0.133 & 0.024 & 0.112 & 0.004 & 0.011 & 0.013 & 0.033 & 0.020 & 0.026 \\
\hline Total & 2 & 2 & 2 & 2 & 2 & 2 & 2 & 2 & 2 \\
\hline \multicolumn{10}{|l|}{ mol.\% } \\
\hline $\mathrm{CaCO}_{3}$ & 97.84 & 98.74 & 97.67 & 99.80 & 99.47 & 99.38 & 98.44 & 99.01 & 98.74 \\
\hline $\mathrm{MgCO}_{3}$ & 2.10 & 1.163 & 2.230 & 0.100 & 0.450 & 0.810 & 1.460 & 0.890 & 1.170 \\
\hline Total & 99.94 & 99.90 & 99.90 & 99.90 & 99.92 & 100.19 & 99.90 & 99.90 & 99.91 \\
\hline
\end{tabular}


(2.5-7.93) for $\mathrm{MgCO}_{3}$ (Table 2). This observation suggested that the amount of exsolving dolomite may be different even within the same sample. Furthermore, these differences in temperature values may be a consequence of either thermal disequilibrium at the peak of metamorphism or a more or less partial re-equilibration of carbonates at lower temperatures during the late stage of metamorphism.

Based on the investigation carried out on the selected samples, curves of $d_{104}$ values and lattice constants $a_{\mathrm{o}}$ and $c_{\mathrm{o}} v s$. $\mathrm{MgCO}_{3}$ content in the coexisting calcite-dolomite were constructed (Figs. 7 and 8). The variation of $d_{104}$ values and cell parameters with the $\mathrm{MgCO}_{3}$ content displayed a nearly linear relationship comparable with the work reported by Goldsmith et al. (1961), and Goldsmith and Graf (1958). The Rietveld refinements showed good agreement between calculated diffraction patterns and observed XRD patterns (Fig. 9). The difference between the refined $d_{104}$ values and XRD patterns were generally $<0.002 \AA$.

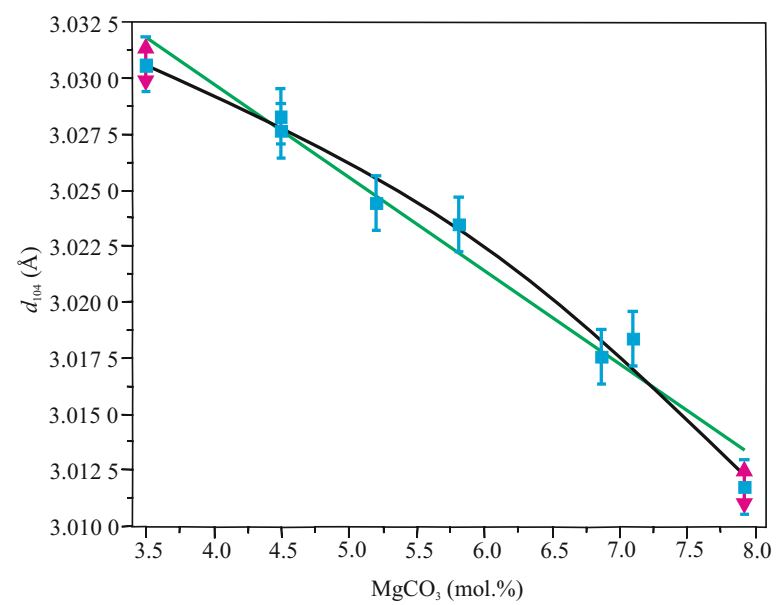

Figure 7. An empirical curve between $d_{104}$ values and mol.\% of $\mathrm{MgCO}_{3}$ of some marble samples from Nowshera Formation and Nikani Ghar marble from the present study. The errors associated with $d_{104}$ values calculated from the Rietveld refinement are also shown. The straight (green) line is the idealized curve (Goldsmith et al., 1961; Goldsmith and Graf, 1958).

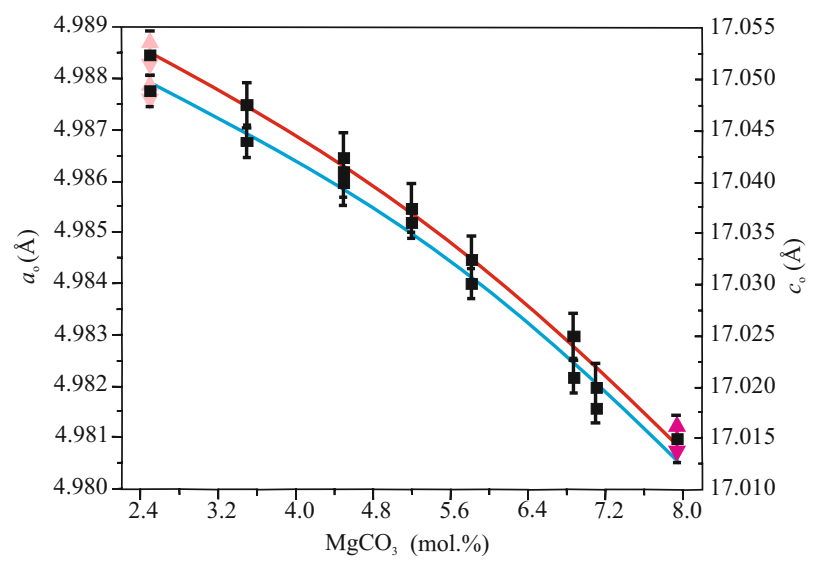

Figure 8. Diagram illustrating the relationship between $a_{\mathrm{o}}$ (red colour), $c_{\mathrm{o}}$ (blue colour) values, and mol.\% of $\mathrm{MgCO}_{3}$ of some marble samples from Nowshera Formation and Nikani Ghar marble from the present study. The errors associated with $a_{0}, c_{0}$ values calculated from the Rietveld refinement are also shown.

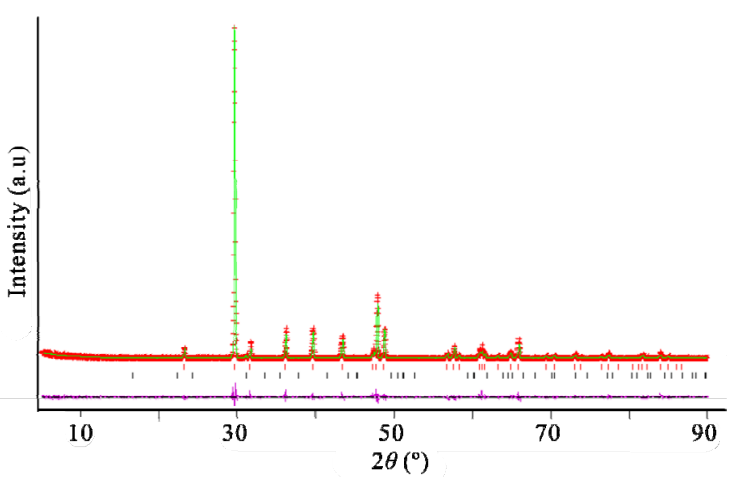

Figure 9. A typical Rietveld refinement result of representative sample BN35. The purple colour curve at the bottom indicates residuals between the measured and calculated patterns.

\section{CONCLUSIONS}

The present results indicate a rather wide range of temperatures derived from Mg-calcite. All the investigated samples contained both calcite and dolomite. The highest temperature determined (Table 2), was $628{ }^{\circ} \mathrm{C}$ for the sample from Nowshera Formation (sample NW-612). Petrographic and SEM analyses of dolomite samples indicated different grain sizes. The coarse grained fractions are believed to be primary dolomite equilibrated with calcite during prograde metamorphism. The magnesium substituted at maximum amounts when the highest metamorphic temperature was reached. On cooling, dolomite exsolved from calcite. This exsolved dolomite constitutes the relatively finer grained fraction and appears as a "bleb-like" texture. Nikani Ghar marble samples have shown lower contents of $\mathrm{MgCO}_{3}$ (except sample $\mathrm{BN}-35$ ) as compared to samples from Nowshera Formation (except samples NW-714 and NW-815). The quartz-bearing calcite-dolomite marble has also showed relatively lower $\mathrm{MgCO}_{3}$ content and hence rather low temperature $\left(\sim 500{ }^{\circ} \mathrm{C}\right)$. The metamorphism temperature of calcite-dolomite marble ranges from 414 to $628{ }^{\circ} \mathrm{C}$. Metamorphic temperatures derived from the present study (shown as a linear graph and table) were in good agreement with those of Goldsmith and Newton (1969). Based on the investigation carried out on selected specimens, curves of $d_{104}$ values and lattice constants $a_{\mathrm{o}}$ and $c_{\mathrm{o}}$ vs. the $\mathrm{MgCO}_{3}$ content in the coexisting calcite-dolomite were constructed. The Rietveld refinements showed good agreement (within $<0.002 \AA$ ) between the observed and calculated XRD patterns in terms of $d_{104}$ values. Metamorphic grade of rocks from the Peshawar Basin have mostly been assessed by their tectonic position and/or mineralogy. These results will provide an alternative view and estimation.

\section{ACKNOWLEDGMENTS}

The authors acknowledge the financial support extended by the Higher Education Commission (HEC), Pakistan and National Academy of Sciences (USA), project ID 131, under the PAK-USA S \& $\mathrm{T}$ Cooperation Program, Award (No. 0521315). The authors are grateful to the HEC, Pakistan for their support in the form of "International Research Support Initiative Program (IRSIP)" to conduct a part of research at Department of Earth Sciences, University of Cambridge, United 
Kingdom. The financial support extended by the Directorate of $\mathrm{S} \& \mathrm{~T}, \mathrm{KP}$ regarding minerals upgradation is also acknowledged. The final publication is available at Springer via http://dx.doi.org/10.1007/s12583-015-0643-7.

Open Access This article is distributed under the terms of the Creative Commons Attribution 4.0 International License (http://creativecommons.org/licenses/by/4.0/), which permits unrestricted use, distribution, and reproduction in any medium, provided you give appropriate credit to the original authors and the source, provide a link to the Creative Commons license, and indicate if changes were made.

\section{REFERENCES CITED}

Ahmad, I., 1986. Geology of Jowar Area, Karakar Pass, Swat District, NWFP, Pakistan: [Dissertation]. National Centre of Excellence in Geology, University of Peshawar, Peshawar. 144-145

Barron, B. J., 1974. The Use of Coexisting Calcite-Ankerite Solid Solutions as a Geothermometer. Contributions to Mineralogy and Petrology, 47(1): 77-80. doi:10.1007/bf00418558

Bickle, M. J., Powell, R., 1977. Calcite-Dolomite Geothermometry for Iron-Bearing Carbonates: The Glockner Area of the Tauern Window, Austria. Contributions to Mineralogy and Petrology, 59: 281-292

Bischoff, W. D., Bishop, F. C., Mackenzie, F. T., 1983. Biogenically Produced Magnesian Calcite Inhomo Geneities in Chemical and Physical-Properties Comparison with Synthetic Phases. American Mineralogist, 68: 1183-1188

Bowman, J. R., Essene, E. J., 1982. P-T-X(CO $\left.\mathrm{CO}_{2}\right)$ Conditions of Contact Metamorphism in the Black Butte Aureole, Elkhorn, Montana. American Journal of Science, 282(3): 311-340. doi:10.2475/ajs.282.3.311

Chave, K. E., 1952. A Solid Solution between Calcite and Dolomite. The Journal of Geology, 60(2): 190-192. doi:10.1086/625949

DiPietro, J. A., Hussain, A., Ahmad, I., et al., 2000. The Main Mantle Thrust in Pakistan: Its Character and Extent. Geological Society, London, Special Publications, 170(1): 375-393. doi:10.1144/gsl.sp.2000.170.01.20

DiPietro, J. A., Lawrence, R. D., 1991. Himalayan Structure and Metamorphism South of the Main Mantle Thrust, Lower Swat, Pakistan. Journal of Metamorphic Geology, 9(4): 481-495. doi:10.1111/j.1525-1314.1991.tb00541.x

Falini, G., Gazzano, M., Ripamonti, A., 1996. Magnesium Calcite Crystallization from Water-Alcohol Mixtures. Chemical Communications, 271(9): 1037-1038. doi:10.1039/cc9960001037

Goldsmith, J. R., Graf, D. L., 1958. Relation between Lattice Constants and Composition of the Ca-Mg Carbonates. American Mineralogist, 43: 84-101

Goldsmith, J. R., Graf, D. L., Heard, H. C., 1961. Lattice Constants of the Calcium-Magnesium Carbonates. American Mineralogist, 46: 453-459

Goldsmith, J. R., Graf, D. L., Joensuu, O. I., 1955. The Occurrence of Magnesian Calcites in Nature. Geochimica et Cosmochimica Acta, 7(5-6): 212-230. doi:10.1016/0016-
7037(55)90033-8

Goldsmith, J. R., Newton, R. C., 1969. P-T-X Relations in the System $\mathrm{CaCO}_{3}-\mathrm{MgCO}_{3}$ at High Temperatures and Pressures. Amer. Jour. Sci. Schairer., 267-A: 160-190

Graf, D. L., Goldsmith, J. R., 1955. Dolomite-Magnesian Calcite Relation at Elevated Temperatures and $\mathrm{CO}_{2}$ Pressure. Geochimica et Cosmochimica Acta, 7: 109-128

Graf, D. L., Goldsmith, J. R., 1958. The Solid Solubility of $\mathrm{MgCO}_{3}$ in $\mathrm{CaCO}_{3}$ : A Revision. Geochimica et Cosmochimica Acta, 13(2-3): 218-219. doi:10.1016/00167037(58)90048-6

Harker, R. I., Tuttle, O. F., 1955. Studies in the System CaO$\mathrm{MgO}-\mathrm{CO}_{2}$; Part I, the Thermal Dissociation of Calcite, Dolomite and Magnesite. American Journal of Science, 253(4): 209-224. doi:10.2475/ajs.253.4.209

Hatcher, R, D., Price, V. Jr., Snipes, P. S., 1973. Analysis of Chemical and Paleotemperature Data from Selected rocks of the Southern Appalachians. Southeastern Geol., 15: $55-70$

Höy, T., 1970. Genesis of Brucite in Marble near Wakefield, Quebec: [Dissertation]. Carleton University, Ottawa

Hussain, A., DiPietro, J. A., Pogue, K. R., et al., 2004. Geological Map of the ${ }^{43}$ B Degree Sheet, NWFP, Pakistan. Degree Sheet Map Series, Geological Map No. 11. Geological Survey of Pakistan, Quetta

Hutcheon, I., Moore, J. M., 1973. The Tremolite Isograd near Marble Lake, Ontario. Canadian Journal of Earth Sciences, 10(6): 936-947. doi:10.1139/e73-082

Iii, D. P., Essene, E. J., Marcotty, L. A., 1982. Thermometry and Barometry of some Amphibolite-Granulite Facies Rocks from the Otter Lake Area, Southern Quebec. $\mathrm{Ca}$ nadian Journal of Earth Sciences, 19(9): 1759-1774. doi:10.1139/e82-155

Kazmi, A. H., Rana, R. A., 1982, Tectonic Map of Pakistan, Geological Survey of Pakistan, Quetta. 1

Larson, A. C., Dreele, R. B. V., 1994. General Structure Analysis System (GSAS). Los Alamos National Laboratory, Report LAUR 86-748, Los Alamos

Lawrence, R. D., Snee, L. W., Rosenberg, P. S., 1985. Nappe Structure in a Crustal Scale Duplex in Swat, Pakistan. Geol. Soc. Am. Abst. Programs, 17: 640-641

Milliman, J. D., Gastner, M., Müller, J., 1971. Utilization of Magnesium in Coralline Algae. Geological Society of America Bulletin, 82(3): 573-580. doi:10.1130/00167606(1971)82[573:uomica]2.0.co;2

Nesbitt, B. E., Essene, E. J., 1982. Metamorphic Thermometry and Barometry of a Portion of the Southern Blue Ridge Province. American Journal of Science, 282(5): 701-729. doi:10.2475/ajs.282.5.701

Pogue, K. R., Wardlaw, B. R., Harris, A. G., et al., 1992. Paleozoic and Mesozoic Stratigraphy of the Peshawar Basin, Pakistan: Correlations and Implications. Geological Society of America Bulletin, 104(8): 915-927. doi:10.1130/0016-7606(1992)104<0915: pamsot>2.3.co;2

Powell, R., Condliffe, D, M., Condliffe, E., 1984. CalciteDolomite Geothermometry in the $\mathrm{CaCO}_{3}-\mathrm{MgCO}_{3}-\mathrm{FeCO}_{3}$ : An Experimental Study. Journal of Metamorphic Geology, 2: $33-42$ 
Puhan, D., 1976. Metamorphic Temperature Determined by Means of the Dolomite-Calcite Solvus GeothermometerExamples from the Central Damara Orogen (South West Africa). Contributions to Mineralogy and Petrology, 58(1): 23-28. doi:10.1007/bf00384741

Ralph, K., Diane, G., 1980. Occurrence, Mineral Chemistry, and Metamorphism of Precambrian Carbonate Rocks in a Portion of the Grenville Province. Journal of Petrology, 21(3): 573-620. doi:10.1093/petrology/21.3.573

Raz, S., Weiner, S., Addadi, L., 2000. Formation of HighMagnesian Calcites via an Amorphous Precursor Phase: Possible Biological Implications. Advanced Materials, 12: 38-42

Rice, J. M., 1977. Contact Metamorphism of Impure Dolomitic Limestone in the Boulder Aureole, Montana. Contributions to Mineralogy and Petrology, 59(3): 237-259. doi:10.1007/bf00374555

Rietveld, H. M., 1967. Line Profiles of Neutron PowderDiffraction Peaks for Structure Refinement. Acta Crystallographica, 22(1): 151-152. doi: $10.1107 / \mathrm{s} 0365110 \times 67000234$

Rietveld, H. M., 1969. A Profile Refinement Method for Nuclear and Magnetic Structures. Journal of Applied Crystallography, 2: 65-71. doi:10.1107/s0021889869006558

Rosenberg, P. S., 1985. Himalayan Deformation and Metamorphism of Rocks South of the Main Mantle Thrust in Southern Swat, Pakistan: [Dissertation]. Oregon State
University, Corvallis, Oregon

Sheppard, S. M. F., 1966. Carbon and Oxygen Isotope Studies in Marble: [Dissertation]. McMaster University, Hamilton Sobol, J. W., 1973. The Petrology of Grenville Marbles in the Vicinity of Bancroft, Ontario: [Dissertation]. University of Michigan, Michigan

Suzuki, K., 1977. Local Equilibrium during the Contact Metamorphism of Siliceous Dolomites in Kasuga-Mura, GifuKen, Japan. Contributions to Mineralogy and Petrology, 61(1): 79-89. doi:10.1007/bf00375946

Talantsev, A. S., 1976. Dolomite-Calcite Geothermobarometer. Dokl. Earth Sci. Sect., 228: 166-168

Talantsev, A. S., 1978. Revision of the Calcite-Dolomite Geothermobarometer. Geochem. Int., 15: 108-116

Toby, B. H., 2001. EXPGUI: A Graphical User Interface ForGSAS. Journal of Applied Crystallography, 34(2): 210-213. doi:10.1107/s0021889801002242

Wada, H., Suzuki, K., 1983. Carbon Isotopic Thermometry Calibrated by Dolomite-Calcite Solvus Temperatures. Geochimica et Cosmochimica Acta, 47(4): 697-706. doi:10.1016/0016-7037(83)90104-7

Zhang, F., Xu, H., Konishi, H., et al., 2010. A Relationship between $D_{104}$ Value and Composition in the CalciteDisordered Dolomite Solid-Solution Series. American Mineralogist, $\quad$ 95(11-12): 1650-1656. doi:10.2138/am.2010.3414 